\title{
Concepts and Compromise in First Amendment Religious Doctrine
}

\author{
Phillip E. Johnson $\dagger$
}

The first amendment's rehgion clauses have perplexed commentators and Supreme Court Justices for some time. ${ }^{1}$ The difficult body of doctrine derived from these clauses seems to consist of contradictory principles, vaguely defined tests, and eccentric distimctions. Present legal doctrines cannot even clann the support of history with much plausibility. Despite the customary invocation of James Madison and Thomas Jefferson, whose views on this subject were complex and in any event not necessarily shared by the other Franers, scholars know that the present doctrinal approach stems from post-World War II Supreme Court decisions. ${ }^{2}$ In an important sense, contemporary doc-

$\dagger$ Professor of Law, Boalt Hall School of Law, University of California, Berkeley. A.B. 1961, Harvard University; J.D. 1965, University of Chicago.

My colleagues Michael Smith and Jesse Choper encouraged my imterest in this subject in the course of many stimulating conversations, and nuy student assistant Mark Ryland also provided valuable critical input.

1. "Candor compels acknowledgment . . that we can only dimly perceive the lines of demarcation in this extraordinarily sensitive area of constitutional law." Leenon v. Kurtzman, 403 U.S. 602, 612 (1971). See also Committee for Pub. Educ. v. Regan, 444 U.S. 646, 662 (1980); Tilton v. Richardson, 403 U.S. $672,677-78$ (1971).

2. For a recent treatınent of the historical background of the religion clauses, see R. CORD, Separation OF ChuRch and STATE (1982), which disputes the "strict separationist" interpretation previously advanced in L. PFefFer, God, CAesar aND the Constitution (rev. ed. 1967).

Professor Mark De Wolfe Howe wrote that in the religion cases, "[T] $T$ he Court has too often pretended that the dictates of the nation's history, rather than the mandates of its own will, contpelled a particular decision. By superficial and purposive interpretations of the past, the Court has dishonored the acts of the historian and degraded the talents of the lawyer." M. HowE, THE GARDEN AND THE WILDERNESS 4 (1965). The historical evidence is debated in the majority and dissenting opimions in Marsh v. Chambers, 103 S. Ct. 3330 (1983) and Lynch v. Donnelly, 104 S. Ct. 1355 (1984).

The practices of the early Presidents are cited by people on both sides of the religion debate. For example, proponents of the "wall of separation" theory einphasize that Presidents Jefferson and Jackson refused to issue proclamations of National Days of Thanksgiving, whereas adherents of the "benevolent neutrality" theory note that Presidents Washington, Adams, and Madison (as well as more recent presidents) issued numerons such proclamations, expressing the nation's gratitude to God and imploring Hun for His blessing. See Lynch, 104 S. Ct. at 1360. James Madison, the principal drafter of the establishment clause, was a nember of the committee that selected a chaplain to open the sessions of the First Congress with prayer, and he voted for the bill authorizing payment of the chaplaim. See Marsh, $103 \mathrm{~S}$. Ct. at 3333 n.8. On the other hand, his "Detached Meinoranda," written after his retirement from politics many years later, disapproved the practice. Id. at 3343-44. Even President Jefferson negotiated a treaty with the Kaskaskia Indians, one condition of which was a pledge by the United States to support a Catholic priest in his priestly duties, and Jefferson repeatedly supported federal land grant trust laws that subsidized 
trine has reversed the original understanding and literal meaning of the first amendment. What was imtended to keep the federal government (Congress) out of church-state relations has become a inandate allowing the federal government (i.e. the federal courts) to regulate those relations in every detail. ${ }^{3}$

That in some sense the federal government and the states ought to be "neutral" in rehigious matters is undisputed, but there is significant disagreement over how benevolent that neutrality should be and how rigorously it ought to be enforced. Practically everyone agrees that government ought not to take sides between Catholic, Protestant, and Jew. It is not equally clear, however, that government can or should be neutral as between atheism and theisin, ${ }^{4}$ nor is it clear whether neutrality implies strictly excluding sectarian syınbols from public ceremonies or displays. ${ }^{5}$ The Supreme Court seems at times to treat any government assistance to rehious activities as a forbidden establishwnent, yet at other times, it requires governments to take extraordinary

missionaries to spread their religion to the Indians. See R. CoRD, supra, at 17-47. As rector of the University of Virginia, Jefferson supported on-campus religious instruction by sectarian divinity scliools. See McColluin v. Board of Educ., 333 U.S. 203, 245 n.11 (1948) (Reed, J., dissenting).

Whatever one might conclude froin the conflicting statements and actions of the early Presidents, the judiciary did not interpret the establishment clause to require strict separation of government and religion until Everson v. Board of Educ., 330 U.S. 1 (1947). "Before that tine, the Supreıne Court readily upheld government actions concerning rehigion that seem lighly problematic by present standards." Smith, The Special Place of Religion in the Constitution, 1983 SuP. CT. REV. 83, 86.

3.

The application of the religion clauses to the states through the due process clause of the fourteenth amendment, the inovement froin a government of closely limited powers to the affirmative state, and the gradual expansion of our understandimg of the nature of religion, lave combined to work a fundamental transformation in the question of how religious groups and interests should be treated. In this context, the religion clauses, which for the framers represented relatively clear statements of highly compatible goals, have taken on new and varied ineanings that frequently appear to conflict.

L. Tribe, American Constitutional Law 812 (1978).

4. "We are a religious people whose institutions presuppose a Supreme Being." Zoracl v. Clauson, 343 U.S. 306, 313 (1952) (opmion of Douglas, J.). Cf. Lyncl v. Donnelly, 104 S. Ct. 1355, 1381 (1984) (Brennan, J., dissenting) (footnote and citation ounitted):

While I remain uncertain about these questions, I would suggest that sucl practices as the designation of "In God We Trust" as our national inotto, or the references to God contained in the Pledge of Allegiance can best be understood . . . as a form of "ceremonial deisn," protected froin Establishment Clause scrutiny chiefly because they have lost through rote repetition any significant religious content.

The phrase "under God" in the Pledge of Allegiance is, however, a recent addition.

Professor Howe argued that the constitutional separation of churcl and state reflected more the evangelical faith of Roger Williams than the skeptical rationalisin of Thounas Jefferson, and that this separation, understood from an evangelical perspective, "endorsed a lost of favoring tributes to faith-tributes so substantial that they have produced in the aggregate what may fairly be described as a de facto establishment of religion." M. Howe, supra note 2, at 11.

5. See Lynch v. Donnelly, 104 S. Ct. 1355, 1360-61 (1984). 
measures to accommodate unusual religious practices. ${ }^{6}$ Despite the most determined efforts of the Justices and the scholars, no single logical framework seems capable of explaining the law.

Many areas of constitutional law are unsettled, of course, but in most areas the uncertainty concerns how far the Constitution requires us to go in a particular direction. In the religion clause area, even the general direction is often difficult to ascertain. For example, if a state decided to experiment with school vouchers as an alternative to the public schools, it could not know whether it would be constitutionally obligated to allow those vouchers to be used at rehigious as well as secular private schools, or whether it would be constitutionally forbidden to do so; whether it would have the discretion to decide the inatter either way without constitutional violation; whether it would be required to give religious schools less money than secular scliools to avoid subsidizing the explicitly religious aspects of the curriculum; or whether it would be forbidden to use the voucher alternative altogether because whatever it did with respect to religious schools would be unconstitutional. ${ }^{7}$ The Supreine Court's recent decision in Widmar v. Vincent ${ }^{8}$ illustrates the conceptual chaos that pervades this area of the law. A Christian student group at the Uinversity of Missouri had been using a room on cainpus for worship ineetings. University officials stopped the practice, citing a state constitutional provision that the state courts had held to require a stricter "separation" of church and state than that mandated by the establishment clause of the federal constitution. ${ }^{9}$ The students, on the contrary, claimed that it was a violation of their rights under the free exercise clause to refuse to allow student religious groups to use campus facilities on the saine basis as secular student organizations. They also argued that this singling out of religious activities for special adverse treatınent violated their rights to equal protection of the laws and freedom of speech, because it distinguished among student ineetings on the basis of the content of their speech.

The federal district court agreed with the university administration that providing a room was an imperumissible establishment of religion. ${ }^{10}$ The court of appeals disagreed, siding with the students. ${ }^{11}$

6. Compare, e.g., McCollum v. Board of Educ., 333 U.S. 203 (1948) and Committee for Pub. Educ. v. Nyquist, 413 U.S. 756 (1973) with, e.g., Sherbert v. Verner, 374 U.S. 398 (1963).

7. See Mueller v. Allen, 103 S. Ct. 3062 (1983) (upholding state tax deduction for limited educational expenses at private and public schools); Widmar v. Vimcent, 454 U.S. 263 (1981) (holding that to deny student religious group use of facilities generally open to other student groups violates first amendment); Committee for Pub. Educ. v. Nyquist, 413 U.S. 756 (1973) (disapproving tuition grants for low-incoune parents who send children to nonpublic schools).

8. 454 U.S. 263 (1981).

9. Id. at $275-76$.

10. Chess v. Widinar, 480 F. Supp. 907 (W.D. Mo. 1979), remanded, 635 F.2d 1310 (8th Cir. 1980), aff'd sub nom. Widmar v. Vincent, 454 U.S. 263 (1981).

11. Chess v. Widmar, 635 F.2d 1310 (8th Cir. 1980), aff'd sub nom. Widmar v. Vincent, 454 U.S. 263 (1981). 
Both decisions are equally rational in terms of conventional constitutional law. Providing facilities such as ineeting rooms certainly aids the religious activity, much as if the state were to make a direct cash grant to pay the rent on a church building. ${ }^{12}$ Yet, one can hardly describe as "neutral" a state policy that provides meeting rooms to Republicans, communists, musicians, and stamp collectors, but denies similar facilities to religious groups. ${ }^{13}$ Such discrimination seems to imply that religion is a peculiarly disfavored activity.

The Supreme Court eventually decided the case on free speech grounds, ruling that worship is a form of communication and invoking the familiar principle that a state may not ordinarily favor one speaker over another on the basis of the content of their speech. ${ }^{14}$ The decision thus held the state constitution's ban on aid to sectarian activities unconstitutional as applied.

Justice White, in dissent, was gravely troubled by the Court's willingness to categorize worship as speech for constitutional purposes. ${ }^{15}$ He pointed out that the Supreme Court itself has gone to great lengths to exclude this particular type of speech from the public school classroom. ${ }^{16}$ When the Supreme Court decides that a school teacher may not lead her class in reciting the Lord's Prayer but may lead it in reciting the Pledge of Allegiance, ${ }^{17}$ or when the Court decides that a state may not require the posting of the Ten Commandments on classroom walls although it certainly could require the postimg of the ten amendments of the Bill of Rights, ${ }^{18}$ it is certainly making distmctions based on the rehigious content of the speech or writing. The majority's decision in Widmar thus called into question an entire body of doctrime.

First amendment religion doctrime is radically indetermmate in three ways. First, there are what I would call the characterization issues, illustrated by Widmar. ${ }^{19}$ A particular disputed issue can often be characterized in two or more different ways: for example, as an estabhishment clause problem, a free exercise problem, or a free speech prob-

12. See Tilton v. Richardson, 403 U.S. 672 (1971) (establishment clause forbids use of fcdcrally subsidized university facilities for religious purposes).

13. "The University's policy singles out and stigmatizes certain religious activity and, in consequence, discredits religious groups." Chess, 635 F.2d at 1317 (footnote omitted).

14. Widmar v. Vincent, 454 U.S. 263, 277 (1981).

15. Id. at 284-86 (White, J., dissenting).

16. Id.

17. Compare Engel v. Vitale, 370 U.S. 421 (1962) with Wcst Va. State Bd. of Educ. v. Barnette, 319 U.S. 624 (1943). Although religious dissenters may have a right to refuse to salute the flag or recite the Pledge of Allegiance, such patriotic cereinonies are not banned froun classrooms.

18. See Stone v. Graham, 449 U.S. 39 (1980).

19. Widmar v. Vincent, 454 U.S. 263 (1981). 
lem. The constitutional outcome depends largely, though not entirely, on the characterization option that one selects; and, as Widmar and other cases show, no neutral principles govern this determination.

After the characterization decision has been made, a second source of indeterminacy arises when the Court apphies a subjective test to determine whether the practice is forbidden, permitted, or required. For example, in free exercise cases, the Court "balances" the individual's or group's interest in the religious practice against the government's interest in regulating the behavior. Similarly, if the issue is characterized as one involving establishment of rehgion, the Court then considers whether the challenged practice involves a forbidden religious purpose, has a primary effect of advancing or inhibiting rehgion, or threatens to foster an excessive government "entangleinent" with religion. But as with the characterization issue itself, these subjective-test concepts are not really helpful in explaining where to draw the line between what government inay and inay not do im support of religious institutions or practices.

Third and finally, there is no accepted definition of "religion" for constitutional purposes, and no satisfactory definition is likely to be conceived. The significance of this definitional gap has generally been overlooked because inost Supreine Court cases have dealt with Christian groups and practices that are concededly "religious." But first ainendinent law is based upon an assuinption that there is soinething important about "rehigious" practices that differentiates thein from "secular" practices and entitles (or subjects) thein to special constitutional treatment. To the extent that we are unable to identify any factor which distinguishes the religious froin the secular, we call into question whether that special treatment is necessary or even rational.

The first three Parts of this Article develop further this theine of indeterminacy, explaining and illustrating the three areas of uncertainty just summarized. Part IV then explores the ideological considerations that might inotivate the Justices to exercise their opportunities to mampulate doctrine im one direction rather than another.

\section{The Characterization Issue}

Judges and coininentators have often observed that the free exercise and the estabhishment clauses look im opposite directions, so that a direct conflict may arise if one is allowed to intrude into territory properly belonging to the other. ${ }^{20}$ What is less frequently noted is that many significant problems can be categorized so as to fall under the

20. See Walz v. Tax Comm'n, 397 U.S. 664, 668-69 (1970); L. TRIBE, supra note 3, at 815; 
rule of either the establishment clause or the free exercise clause, depending upon which we would prefer to have govern the situation.

\section{A. Aid to Religious Private Schools}

A good example of this characterization problem is the perennially controversial question of whether it is a forbidden "estabhishment of rehigion" for a state legislature to provide soine assistance to rehigious schools, or the students in thein, as part of a general prograin of assistance to private education. If we view the transfer of funds to religious schools (with or without the parents or students as a conduit ${ }^{21}$ ) in isolation, the program seeins to be providing a special benefit to religious activity, and thus it is at a minimuin constitutionally suspect. That is precisely how the federal district court viewed the use of facilities for student worship in Widmar. ${ }^{22}$ On the other hand, we could equally logically focus on the state educational prograin as a whole and view the tuition grants or whatever as a rough atteinpt to "equalize" the treatinent of those parents and students who desire a rehigious education with those who prefer a secular education. In that case we would understand the state's action not as an atteinpt to benefit rehioion, but as an attempt to avoid disadvantaging or discriminatimg against it.

Relatedly, it has long been assumed that parents have a right under the free exercise clause to send their children to religious schools if they can do so at their own expense. ${ }^{23}$ It is not obvious that the religious liberty of the children is always furthered by allowing their parents to choose a sectarian education, ${ }^{24}$ or that a "compelling interest" could not be found to justify a law requiring all children to go through the socializing experience of public education. ${ }^{25}$ Nonetheless, the parental right is well established and not controversial.

Granted that premise, it is difficult to understand how it can be impermissible for a state to inake the same option available to everyone

Choper, The Religion Clauses of the First Amendment: Reconciling the Confict, 41 U. PITT. L. REv. 673, 690-92 (1980).

21. For establishment clause purposes, Supreme Court holdings indicate that it makes some difference if the state channels the aid to religious schools through individual parents. See Mueller v. Allen, 103 S. Ct. 3062, 3069 (1983).

22. "[T]his Court finds that a university policy permitting regular religious services in university-owned buildings would have the primary effect of advancing religion." Chess v. Widmar, 480 F. Supp. 907, 915-16 (W.D. Mo. 1979), remanded, 635 F.2d 1310 (8th Cir. 1980), affd sub nom. Widmar v. Vincent, 454 U.S. 263 (1981).

The issue, of course, is whether one characterizes the policy as a policy permitting religious services or as a policy permitting student activities generally.

23. Wisconsin v. Yoder, 406 U.S. 205, 213-14 (1972); cf. Pierce v. Society of Sisters, 268 U.S. 510 (1925) (holding Oregon statute requiring children between the ages of eight and sixteen to attend public schools unconstitutional).

24. See Yoder, 406 U.S. at 241-46 (Douglas, J., dissenting).

25. See id. at $237-41$ (White, J., concurring). 
by tuition tax credits, grants, or other forms of aid to private schools. Looked at that way, the question should not be whether it is a permissible activity for the state to provide aid to religious schools, but whether the Constitution permits a state (or even conceivably requires it) to give the poor the kind of opportunities for educational choice that the rich and middle class currently enjoy.

The issue in the assistance-to-schools cases is analogous to that involved in Widmar, except that nuch more is at stake. The problein is that government is simultaneously forbidden from giving substantial assistance to rehgious activities and from discriminating against religious activities. When the question is whether rehgious organizations should be allowed to receive funding or use facilities on the saine basis as secular organizations, the primciples of "no assistance" and "no discrimination" coine into conflict. ${ }^{26}$

One can deny the existence of the conflict by denying that "religious" and "secular" educations are the appropriate things to be coinpared. A person taking this view would probably prefer to label the public schools of the United States as "neutral" rather than "secular." Our public schools do not endorse any particular religious positionChristianity, Judaism, Islam, or whatever-nor do they preach atheism, as the schools in the Soviet Union are said to do. The schools avoid controversial religious questions not because the school authorities have concluded that those questions are not important, but rather because they think religious instruction is best carried on in homes or churches free of governmental involvement. From this viewpoint, the only way to be neutral about rehion is to ignore the subject altogether. ${ }^{27}$

Whether schools that avoid the topic of religion altogether are thereby "neutral" towards rehgion is debatable. For one thing, the schools have to teach subjects-biology in particular-which touch directly upon nuatters of rehigious controversy. A textbook that teaches that the human species evolved gradually over millions of years froin simple hife forms is anything but neutral from the viewpoimt of Biblical literalists. Courses in social hiving, "values clarification," and sex education also produce religious controversy, because opinions about sexual norality and other ethical issues are so closely related to religious behiefs. ${ }^{28}$

26. The conflict between the "no assistance" and "no discrimination" principles was apparent even in the first Supreme Court decision on aid to parochial schools. See Everson v. Board of Educ., 330 U.S. 1, 16-18 (1947).

27. See infra note 115 and accompanying text.

28. See Eger, The Confict in Moral Education: An Informal Case Study, PuB. INTEREST, Spring 1981, at 62. 
For example, is heterosexual, life-long marriage the ideal sexual relationship to which all others are unfavorably compared, although others may be legally tolerated, or should various "hiving together" arrangements, mcludimg homosexual haisons, be regarded as equally acceptable alternatives? Should pregnant teenagers be encouraged to consider abortion as a morally respectable alternative to raising the child or offering it for adoption? No matter how hard the schools try to straddle that sort of question, they are drawn irresistibly towards either reinforcing the traditional rehgion-based sexual morahty without explaining its theological foundation, or towards emphasizing informed personal choice as the ultimate criterion. ${ }^{29}$

The point here is not that the public schools are doing something wrong in teaching evolutionary biology, or stressing the practical problems of teenage sex (i.e., contraception and disease prevention) rather than its ultimate morahity. The schools ought to teach their students what they need to know, whether or not the teaching touches on controversial subjects. But what do the students need to know, and what do they need to be warned against? One's rehgious commitments necessarily affect how one answers those questions. To put the point another way, what matters is not so much what the schools do or do not exphicitly teach their students about rehgion, but what assumptions about the nature of humanity and the purpose of life guide the school authorities im planning the curriculuin and admimistering the hife of the school..$^{30}$ Although it is possible to be more or less fair minded about such matters, there is no such thing as a dead-center neutrahty in comparison to which all other positions are partisan.

\section{B. Unemployment Compensation}

Characterization problems also arise in other contexts. For example, the Supreme Court held in Sherbert v. Verner ${ }^{31}$ that the free exercise clause requires states to pay unemployment compensation to Seventh-Day Adventists who refuse to accept employment that requires Saturday work. By contrast, critics such as Dean Choper have argued that not only was this result not required by the free exercise

29. See Kasun, Turning Children into Sex Experts, PuB. Interest, Spring 1979, at 3. For a further exchange on the sex education controversy, see Crosbie, Sex Education: Another Look, Pub. Interest, Winter 1980, at 120; Kasun, More on the New Sex Education, Pub. INTEREST, Winter 1980, at 129.

30. For example, in a relatively permissive society, public sclools are also likely to be permissive. Religious schools attract many students (or parents) by offering a more structured and disciplined learning environment. A school does not have to be religious in order to be strict, of course, but many religious schools do stress discipline. Perliaps a firm commitment to a set of beliefs-whether or not labeled as religious-predisposes school authorities to be firn with their students.

31. 374 U.S. 398 (1963). 
clause, but it actually violates the establishment clause by giving to Saturday worshipers a privilege that would be denied to persons who refuse to accept Saturday employment for nonrehious reasons. ${ }^{32}$

The difference in characterization depends upon what is compared with what. Dean Choper compared the position of strict Saturday worshipers with that of persons who prefer not to work on Saturday for nonreligious reasons. ${ }^{33}$ From his perspective, the former group received a benefit that the latter group did not. The Supreme Court majority, on the other hand, thought it more appropriate to compare the situation of Saturday worshipers with that of Sunday worshipers, whose freedom to refuse work on Sunday was solidly protected by law. ${ }^{34}$ Because it would involve little added expense or imconvenience to the state to make an adjustment for Saturday worshipers, the Court saw doing so as a fair-minded attempt to equalize the treatment of persons adhering to different creeds.

As in the aid-to-schools cases, one could resist this logic by describing Sunday as the "neutral" day of rest recognized by the state for secular purposes, rather than as a day set apart because of its significance to orthodox Christians. On that basis, the Supreine Court has held that states may forbid businesses to operate on Sunday, ${ }^{35}$ and to the extent that businesses are closed on Sunday, the question of willingness to work on that day will not arise. Where Sunday work is permitted, on the other hand, a policy of strict neutrality requires that both religious and nonrehigious persons who refuse to work on Sundays be treated alike for uneinployment compensation purposes, and that persons who refuse to work on other days for religious reasons be given no special dispensation. By granting no religious exemptions at all, the state can avoid having to answer thorny hypothetical questions sucli as how it should treat an eccentric group that requires its members to refuse to work on Wednesdays. In practice, Saturday worshipers and not Sunday worshipers would probably have to accept eniployment on their day of worship, due to Sunday closing laws and related custorns, but at least the law would be formally neutral if not equal in effect, and the state could avoid the quagmire of individualized exceptions for religious claims.

II

\section{The Subjective Tests}

Although it is an important first step, the characterization decision

32. Choper, supra note 20 , at $690-92$.

33. Id. at 691 .

34. Sherbert v. Verner, 374 U.S. 398, 406 (1963); see also Choper, supra note 20, at 692-95.

35. McGowan v. Maryland, 366 U.S. 420 (1961). 
does not necessarily control the outcome of a rehigion case. If we find that a state regulation or command burdens someone's free exercise of rehion, then that burden must be justified by a "compelling state imterest" that cannot be satisfied in some other, less intrusive manner. If we decide mstead that we are dealing with a possibly forbidden establishment of rehgion, then the benefit is nonetheless constitutional if the questioned act can pass a three-part test formulated by the Supreme Court im Lemon v. Kurtzman: ${ }^{36}$ it must have a secular purpose, its primcipal or primary effect must be one that neither advances nor inhibits religion, and it must not foster " 'an excessive government entanglement with rehgion.' "37

At tinnes, however, the Court disregards the Lemon test in establishment clause cases if its application would lead to mconvenient outcomes. A leading example is Marsh $v$. Chambers, ${ }^{38}$ where a six-to-three majority allowed the Nebraska Legislature to contimue its long-standing practice of paymg a Protestant clergyman to open each day of the legislative session with a nondenommational prayer "im the JudeoChristian tradition." 39 Legislative prayer seems like a clearcut endorsement of theistic religious belief, despite the effort to avoid sectarian controversy, but the Supreme Court found constitutional support for the practice in a tradition datimg back to the Contimental Congress and the founding of the nation. ${ }^{40}$ Perhaps the holding can best be explamed by adding a fourth element or exception to the Lemon test: ceremonial governmental religious pronouncements are not unconstitutional if they are sufficiently "traditional," and if they are not made in the public schools.

The Lemon test has been ridiculed because of the seemingly absurd lines that the Supreme Court has drawn in its name, especially im the area of public aid to religious schools. One example is particularly notorious: the Supreme Court has permitted states to provide free secular textbooks to parochial school students, but has forbidden as an establishment of religion the furmshing of "mstructional materials," such as maps. ${ }^{41}$ There is nothing about the Lemon test itself, lowever,

36. 403 U.S. 602 (1971).

37. Id. at 612-13 (quoting Walz v. Tax Comm'n, 397 U.S. 664,674 (1970)). The Lemon test is also sometimes discussed in free exercise cases, when the issue is whether a religiously motivated individual or group should have an exemption from soune broadly apphicable regulation. See, e.g., Wisconsin v. Yoder, 406 U.S. 205, 234 n.22 (1972). If granting that exemption would run afoul of the test used to determine when assistance to rehigion violates the establishment clause, then we would have a perfect standoff between the two clauses. The free exercise might conceivably require what the establishment clause forbids.

38. 103 S. Ct. 3330 (1983).

39. Id. at 3336 (footnote omitted).

40. Id. at 3333-36.

41. See generally Wolman v. Walter, 433 U.S. 229 (1977). 
that required the Supreme Court to draw the line where it did rather than somewhere else. The problem with the Lemon test is not that it requires drawing lines, but rather that its three concepts-rehgious purpose, religious effect, and entanglement-do not help us to decide where the lines should be drawn. At the same time, they create further characterization problems. Finally, it is not clear why these concepts are even relevant.

\section{A. Religious Purpose or Effect}

Consider, for example, the difficulty of making sense out of the crucial distinction between religious purpose or effect and secular purpose or effect. Governments usually act out of secular motives, even when they are directly aiding a particular religious sect. An atheistic ruler might well create an established church because he thinks it a useful way of raising money, or of ensuring that the clergy do not preach seditious doctrines. ${ }^{42}$ In democratic societies, elected officials have an excellent secular reason to accommodate (or at least to avoid offending) groups and individuals who are religious, as well as groups and individuals who are not. They wish to be re-elected, and they do not want important groups to feel that the community does not honor their values.

Moreover, it is generally acknowledged that religious behief influences behavior, whether for better or for worse. A government might have excellent secular reasons for opposing sects that forbid their members to perform military service or that require racial segregation. For similar reasons, the state might want to support sects that teach their adherents to obey the laws or respect the equality of all races. If establishing a religion had no secular purpose, secular rulers would rarely be attracted to the idea.

Clearly, then, it is difficult to tell religious and secular purpose apart, or to say which effect is primary and which secondary. But beyond that, it is difficult to understand why it is necessarily unconstitutional for legislation to have the purpose or effect of assisting religious practice generally, when the Constitution itself gives a special status to religion. The free exercise clause itself can be said to have the purpose and effect of allowing the citizenry to practice their religion freely. Can it be unconstitutional for government to assist the citizens to exercise

42. King Henry VIII disestablished the Church of Rome and estabhished the Church of England because he wanted to divorce his wife and seize the property of the monasteries. Presumably, equally secular motives or effects would not justify an American Congress in establishing a national church. Perhaps estabhshing a church has au inherently religious purpose even when the motive is secular, but then the definition of religious purpose seems to be circular: an act has a religious purpose if it aids rehion in an uncoustitutional manner. 
their constitutional rights under the free exercise clause? But such assistance seeins to have the purpose and effect of aiding rehgion!

The perennial problem of public financial assistance to rehigious schools can once agam be used to illustrate the point. Suppose that a state legislature appropriates money which is to be transferred directly to religious schools to subsidize their operations, coinplete with a preamble announcing that the statutory purpose is to assist parents to exercise their constitutional rights under the free exercise clause, specifically to ensure that their own children receive a rehious education. ${ }^{43}$ Whether that purpose is termed "rehgious" or "secular" is entirely a matter of seinantic choice. The legislation purposely assists rehigious activity, but it also purposely assists people to exercise a right guaranteed by that secular document, the Constitution. One effect of this assistance might be that more youngsters will have religious behefs than would otherwise be the case. But that is also a likely effect of the free exercise clause itself. Perhaps there are excellent reasons for limiting the permissible forms of state aid to rehgious educational imstitutions. The point here is that discussing "religious purpose" and "rehgious effect" is not a useful way of identifying those reasons or deciding what the limitations ought to be.

The notion that it is wrong for legislation to have the purpose or effect of assisting rehgion only makes sense in terms of an assumed "neutral" startimg poimt that defines what advantages or disadvantages religion ought to have. When the federal government supplies chaplaims for the armed services, it clearly means to assist the military personnel to practice their various rehigions. Even Justices who take a strict "wall of separation" approach to most establislıment issues find the military chaplain program acceptable, because they see it as compensation for the difficulties the government creates by removing military personnel from their former environnents. ${ }^{44}$ Provision of routime public services like sewers and fire protection to church-related structures is also rarely questioned, and nobody proposes to deny the use of subsidized public transportation to people who are going to church. ${ }^{45}$ Even very substantial aid in the form of tax exemptions for churches and other religious imstitutions like hospitals and schools is acceptable to most of the Justices, because it can be viewed as treating them like

43. A state would be much more likely to justify such a subsidy on the ground that it compensated the schools for the purely secular societal benefit of education in secular academic subjects. Dean Choper, among others, has argued that subsidies to rehgious schools are justified if they do not exceed the secular benefits of the education to the community. See Choper, supra note 20 , at $675,679-80$. The hypothetical in the text is mcant to state a more difficult example.

44. See Marsh v. Chambers, 103 S. Ct. 3330, 3346 (1983) (Brennan, J., dissenting).

45. See Mueller v. Allen, 103 S. Ct. 3062, 3073 (1983) (Marshall, J., dissenting). 
other similar charitable and educational institutions. ${ }^{46}$

Measures that have the effect of aiding rehigious practices or institutions-as all the stated examples do-become controversial only when people perceive them as going beyond a conventionally accepted norm. Until we know where that norm is located, the test of rehigious purpose or effect is meaningless. Once we have set that norm, it measures the appropriate level and forms of public aid for rehigion, and we can dispense with the Lemon criteria altogether. The constitutionality of subsidies to rehigious schools or employment of either legislative or military chaplaims must turn on the nature of the subsidized activity rather than the subjective purpose of the legislators who voted for the appropriation. Clearly, then, the tests that look to religious purpose or effect do not explain the distinctions that the Court has drawn.

\section{B. Entanglement}

There are equally difficult problems with "entanglement," the third branch of the Lemon test. Entanglement in this context seems to have at least two distmct connotations. In the more literal sense, it means simply "excessive involvement." It is undesirable for the state to become deeply involved in the government or regulation of religious institutions, because such involvement itself may curtail religious freedom or involve the state in controversies with which it is not competent to deal. ${ }^{47}$ For this reason, the Supreine Court has insisted that states permit religious organizations a greater degree of self-government than would be required in the case of secular organizations such as corporations, labor umons, or charities. ${ }^{48}$

A second and more important meaning of entanglement seems to be "divisiveness." Rehigious issues are considered to be particularly likely to arouse strong passions and enmities, especially when one faction or another sees the possibility of enlisting the state to further its cause. $^{49}$ To avoid bitter controversies over what the ștate's role should be, the state should avoid inatters touching on religion to the greatest extent possible. ${ }^{50}$ It is in this sense of divisiveness that entanglement is

46. The issue of tax exemptions for church property used solely for religious worship should have been an extremely difficult one for the Supreme Court, because houses of worship do not provide the kind of "secular benefit" that religious schools and hospitals do. Nonetheless, only Justice Douglas dissented from the decision upholding those benefits in Walz v. Tax Comm'n, 397 U.S. 664, 700 (1970). Possibly the Court was influenced by the fact that many more religious denominations were threatened by the prospect of denial of tax exemptions than were affected by the denial of subsidies for religious schools.

47. See generally Laycock, Towards a General Theory of the Religion Clauses: The Case of Church Labor Relations and the Right to Church Autonomy, 81 CoLUM. L. REv. 1373 (1981).

48. Id.

49. Id. at 1393-94; see also L. TRIBE, supra note 3, at 866-67.

50. See, e.g., Lemon v. Kurtzman, 403 U.S. 602, 622-24 (1971). 
most often used in the cases.

Justification of an active judicial role overseeing state involvement witl religion on the basis of a policy of avoiding divisive entanglements rests upon two problematic factual assumptions. One is that religious disputes and religious people are particularly contentious, so that state involvement in religious matters is more likely to breed bitter conflicts than state involvement in such matters as the distribution of wealth or civil rights. Undoubtedly, religious conflicts liave led to wars and persecutions, as have conflicts over secular ideologies like fascism and communism. What is problcmatic is whetler, in conditions of contemporary American society, matters such as school prayers, legislative chaplains, and Christmas displays are more hotly disputed than many secular inatters with which state legislatures deal routinely. ${ }^{51}$

The second problematic assumption is that courts alleviate divisiveness when they take an issue away from the voters and legislators and decide it on the basis of a constitutional principle. This is a most implausible idea, and sucl evidence as exists seems to be against it. Many of us find it easier to accept being outvoted by a majority of our fellow citizens or their representatives than by a handful of judges. Legislative battles over the issue of legalized abortion seem to have become more bitter and divisive since the Supreme Court attempted to preempt the issue in Roe $v$. Wade. ${ }^{52}$ The very act of deciding a dispute on the basis of some abstract legal principle ratler than on the giveand-take of legislative compromise tends to identify more clearly one side as the winner and the other side as the loser, with the result of increasing the bitterness of the loser.

One sure way to encourage conflict on any subject is to encourage people to think that what seem to be minor irritations are in reality violations of some sacred principle for which they have a duty to figlit. The Supreme Court's decision in Lynch v. Donnelly, ${ }^{53}$ involving the constitutionality of a community's tradition of including a crèclie or nativity scene in its otherwise secular Christmas display, illustrates the tendency of expansive judicial remedies to generate conflict that might not otherwise occur. The crèche had been part of the annual display for at least forty years. The district court found that no controversy existed over it, until local members of the American Civil Liberties Union brought a lawsuit to enjoin its display. ${ }^{54}$ Nonetheless, the dis-

51. See Smith, supra note 2, at 97.

52. 410 U.S. 113 (1973).

53. 104 S. Ct. 1355 (1984).

54. Donnelly v. Lynch, 525 F. Supp. 1150,1180 (D.R.I. 1981), affd, 691 F.2d 1029 (1st Cir. 1982), rev'd, 104 S. Ct. 1355 (1984). 
trict court, ${ }^{55}$ and the dissenting opinion in the Supreme Court by Justice Brennan, ${ }^{56}$ found the divisiveness engendered by the lawsuit itself to be evidence that the Christmas display posed a danger of divisive entanglement, noting that the calm that had prevailed prior to the lawsuit might merely have reflected a feeling on the part of dissatisfied individuals that it would be futile to oppose the majority. ${ }^{57}$

No doubt a sense of futility is a possible explanation for the absence of recorded complaint, but that fact also deinonstrates that, by encouraging persons who are easily offended by religious syınbolism to believe that the courts stand open to remedy their complaints, the courts foster divisive conflicts over retigion. Similarly, by encouraging citizens and legislators to believe that aid to religious schools is a matter to be decided on the basis of abstract constitutional principles rather than by compromise and accommodation, the Supreine Court may well have made such disputes more bitter than they otherwise would be. That consideration does not necessarily mean that the Court has acted wrongly because justice, not doinestic peace, is the primary aim of constitutional adjudication. ${ }^{58}$ American society might be nore peaceful if the Supreme Court stopped enforcing constitutional rights altogether.

\section{III \\ The Definitional Problem: What is "Religion"?}

First amendment religion law proceeds on the assumption that "rehious" activity can and should be treated differently froin otherwise similar activities, sometimes to religion's benefit and sometimes to its detriment. For example, rehgious statements and practices are sometimes exempted from government regulations that apply to other forms of speech or conduct, but as a rule religion is excluded froin public institutions such as the schools. Accordingly, an organization may gain or lose privileges depending upon whether it is classified as reli-

55. Id.

56. Lynch v. Donnelly, 104 S. Ct. 1355, 1374 (1984) (Brennan, J., dissenting).

57. Id.

58. The discussion of entanglement in Lemon v. Kurtzman, 403 U.S. 602 (1971), is particularly perplexing. The majority opinion by Chief Justice Burger praises the enormous contribution that private religious schools have unade to our national life, and observes that taxpayers have saved "vast sums" due to their existence. Id. at 625. Nonetheless, public aid to these schools has such "divisive political potential" that allowing such aid would tend to polarize state politics, and thus "to confuse and obscure other issues of great urgency." Id. at 622-23.

But if religious schools enormously benefit our national life and save taxpayers vast sums of money, why do proposals to assist them arouse such passionate opposition? Is it likely that the opponents of subsidies take so benign a view of religious education? When has public controversy over aid to religious schools actually caused this destructive polarization, and what other issues has it confused or obscured? Above all, who is to blame for this unfortunate state of affairs-the supporters of the subsidies or the opponents? 
gious or secular. The practice of Scientology became the Church of Scientology in part to protect the organization's E-meters and other therapeutic devices and practices from regulation by the Food and Drug Administration. ${ }^{59}$ The cult of Transcendental Meditation, though clearly derived from Himdu religion, sought classification as a therapeutic science in part because it wanted to promote its meditation techniques in the public schools. ${ }^{60}$ On what principle are we to assign groups to one category or the other?

The fact is that no definition of religion for constitutional purposes exists, and no satisfactory definition is likely to be conceived. According to an important article by Dean Clioper, ${ }^{61}$ "the scope of religious pluralism in the United States alone has resulted in such a inultiplicity and diversity of ideas about what is a 'religion' or a 'religious belief' that no simple forinula seems able to accommodate them all."62 Professor Greenawalt's article in this Syinposium carries a similar message: no factor or set of factors lias been found that satisfactorily distmguishes "religion" from philosophy or ideology. ${ }^{63}$

Most Amcricans probably imaginc that religion inherently has soniething to do with the concept of a creator God. But some faiths commonly called religions-Buddhism, for example-have no such doctrine. ${ }^{64}$ In addition, a nuniber of fanous Christian theologians have attempted to "demythologize" their religion by removing all the explicitly supernatural elements that may be uncongenial to the world view of twentieth century rationalists. ${ }^{65}$ Many persons who think of themselves as Christians conceive of God more as an abstract ideal of goodness or "ground of all being" than as a personal being who makes pronouncements to humanity. By contrast, persons who believe that the universe is in some sense rationally ordered, and that there is an objective standard of right and wrong independent of human opinion, may think of themselves as agnostics or atheists because they find the idea of God as an "old man in the sky" to be incredible. The differences among these groups may be more a matter of preferred vocabulary than substance. It would be odd indeed if the Constitution were

59. See Founding Church of Scientology v. United States, 409 F.2d 1146 (D.C. Cir.), cert. denied, 396 U.S. 963 (1969). The E-meter is a skin galvanometer used in some Scientology rituals to measure a person's emotional responses to questions. $1 t$ is believed that through proper interpretation of the E-meter readings, one can determine the inental and spiritual condition of a subject. Id. at 1153 .

60. Malnak v. Yogi, 440 F. Supp. 1284 (D.N.J. 1977), affd, 592 F.2d 197 (3d Cir. 1979).

61. Choper, Defining "Religion" in the First Amendment, 1982 U. ILL. L. REv. 579.

62. Id.

63. Greenawalt, Religion as a Concept in Constitutional Law, 72 CALIF. L. Rev. 753 (1984).

64. See Torcaso v. Watkins, 367 U.S. 488, 495 n.11 (1961); see also Johnson, Do You Sincerely Want to be Radical?, 36 STAN. L. Rev. 247, 288 n.106 (1984).

65. This point is well developed in L. TRIBE, supra note 3, at 826-27. 
read to treat persons very differently on the basis of whether they used or avoided the word "God" in expressing their understanding of the fundamental order or disorder of the universe.

\section{A. The Seeger Dilemma}

It is therefore not surprising that the Supreme Court, on the rare occasions when it has been asked to say anything about the definition of "rehgion" or "religious behef," has indicated that the category must be open ended. In United States v. Seeger, ${ }^{66}$ the Court held that draft exemptions granted to persons who oppose participation im all war "by reason of their rehigious training and belief" must be extended to pacifists who hold any sincere and meaningful belief that "occupies a place in the life of its possessor parallel to that filled by the orthodox belief in God of one who clearly qualifies for the exemption." 67 In another decision, the Court observed that the religion clauses prohibit government support of "those religions based on a belief in the existence of God as against those religions founded on different behefs," noting that "[a]mong rehigions in this country which do not teach what would generally be considered a belief in the existence of God are Buddhism, Taoism, Ethical Culture, Secular Huniamisin and others."68

Such formulations make the category of "religion" seen so allinclusive that it is doubtful whether any system of behefs that people treat as important can be excluded. Perhaps this is as it slould be, because it may be inherently arbitrary to distinguish among beliefs about what is fundamentally real and important on the basis of whether they are conventionally designated as "religious" or not. Consider, for example, Professor Greenawalt's suggestion that, if nonreligion is not religion, government endorseinent of atheisin might not violate the establishment clause. ${ }^{69}$ This possibility is consistent with the ordinary language usage of the term religion. It does seem peculiar, however, that a constitutional clause supposedly dedicated to religious neutrality could be read to permit the government to endorse one side of a religious issue but not the other, particularly when the clause literally forbids not just an "establishment of religion" but rather "a law respecting an establishment of religion."

Thinking this way leads one to a paradox. If the first amendment

66. 380 U.S. 163 (1965); see also Welsh v. United States, 398 U.S. 333 (1970).

67. Seeger, 380 U.S. at $165-66,176,184$. The Seeger opinion purports to be interpreting the Selective Service Act, but the interpretation is so strained that commentators have assumed that the Court had constitutioual considerations in mind.

68. Torcaso v. Watkins, 367 U.S. 488,495 \& n.11 (1961).

69. Greenawalt, supra note 63, at 793-94. Greenawalt concludes that whatever the relevant constitutioual clause, government sponsorship of either religion or antirehgion ought to be disfavored. Id. at 794. 
is supposed to prevent government from favoring one religion over another, or from favoring religion over nonreligion or vice-versa, then how do we explain the special constitutional status for religion that the first amendment itself mandates? Does the first amendinent violate itself, by giving "religion" special immumities and disabilities? Or, if we avoid this problem by construing "rehgion" so broadly that the tern includes all deeply felt beliefs, do we create an impossibly long list of things that government must not "establish" and whose free exercise government inust not hinder?

To soine people the most important thing is God; to others it may be the categorical imperative, the pleasure or pain that humans (and animals?) feel, hunan rights, national glory, the U.S. Constitution, the free narket, the class struggle, the battle of the sexes, the liberation of an oppressed racial or ethnic group, the love of power or fame, the life of the mind, artistic or athletic excellence, the bottle, or the needle. If the appropriate set is beliefs about ultimate reality, as the Supreme Court majority seems to have thought in Seeger,${ }^{70}$ then those opmions about that reality that we conventionally label as "religious" seem to constitute an arbitrarily defined subset.

\section{B. Two Definitions or One?}

Some scholars have suggested that the terin "religion" ouglit to be defined differently for different purposes. Professor Tribe did not even attempt an overall definition in his treatise, but contented himself with the suggestion that nontheistic creeds or philosophies that are both arguably religious and arguably nonreligious should be protected by the free exercise clause, but should be free of the restrictions of the establishinent clause. ${ }^{71}$ An individual who refused to coinply with a law because of a strong moral belief that would not be religious under a narrow definition would be entitled to have his defense considered under the free exercise clause, but a school board could provide for the teaching of that same belief in the public schools without running afoul of the estabhishnient clause. Although the first amendinent uses the word "religion" only once, Tribe thought this dual definition necessary if the establishnient clause was not to becoine "an awful engine of destruction" that would invalidate legislation whose purpose or effect was to advance such arguably religious values as "humnan dignity, equality, national destiny, freedorn, enlightenment, and morahty' . . . especially if the legislation was the result of pressure by church or rehgious

70. See United States v. Seeger, 380 U.S. 163, 176, 184, 186 (1965).

71. L. TRIBE, supra note 3 , at 828-33. 
groups."72

Even if one is willing to allow a term that is used only once in the Constitution to have two definitions, Professor Tribe's approach has the objectionable effect of permitting those groups and persons whose behefs are both arguably rehgious and arguably not religious to claim the benefits of the free exercise clause without incurring the burdens of the establishment clause. ${ }^{73}$ In other words, they could have it both ways, which happens to be the classic definition of unfair preference. Members of traditional, "indisputably religious" cliurclies could hardly be expected to see the dual definition as anything but legalistic flimflam in the service of nontheistic religious ideology. Indeed, if the Supreme Court were to endorse Tribe's reasoning, it would lend support to the claim of some religious fundamentahsts that the public schools and other governmental agencies are currently establishing a form of secular religion.

\section{Getting Along Without a Definition}

Dean Clioper grasped the other horn of the dilemma in his own attempt to define religion for constitutional purposes. He defined "religious belief" as necessarily involving "extratemporal consequences," so that a conscientious objector's claim would only be defined as religious if the objector believed that lie would be punished in the afterlife for participating in war. ${ }^{74}$ This definition has practically nothing to do with how the word religion has been used either in ordinary language or in Supreme Court opimions; Choper chose it solely because he felt that an individual slould not be able to claim an exeinption from a legal obligation (sucli as military service or compulsory scliool attendance) on free exercise grounds, unless he feared punishinent in the afterlife if lie complied. ${ }^{75}$

The important thing is not the definition itself, however, but the limited use Choper makes of it. The definition has practical effect only in free exercise clause cases, where in fact Clioper contemplates that relief from generally applicable laws wonld rarely be granted. ${ }^{76}$ For establishment clause issues, the definition of rehgion is unimportant to

72. Id. at 831 (quoting Galanter, Religious Freedom in the United States: A Turning Point?, 1966 WIS. L. REv. 217, 266).

73. Greenawalt, supra note 63 , at 814 .

74. Choper, supra note 61 , at 597-601.

75.

[A]lthough there is no sure method of proving it scientifically as an einpirical inatter, intuition and experience affirm that the degree of internal trauma on earth for those who have put their souls in jeopardy for eternity can be expected to be markedly greater than for those who have only violated a moral scruple.

Id. at 598 .

76. See Choper, supra note 20 , at $696-700$. 
Choper, because he concludes that government has a general constitutional obligation, independent of the estabhishment clause, to be ideologically neutral with respect to religious and secular creeds alike. ${ }^{77}$ Without sucl1 a general obligation of governmental neutrality, Clioper's definition would have the disturbing consequence of permitting the government to "establish" any doctrine, whether or not conventionally labeled as religious, provided the doctrine did not relate to extratemporal consequences. ${ }^{78}$ In effect, Choper is atteinpting not so much to define religion as to find a way of getting along without a definition.

Given the difficulty of framing a satisfactory definition of religion, there is inuch to be said for trying to treat the "establishment" problem under some more general doctrine. If there really is no clear-cut difference between religious doctrines and nonreligious doctrines, then why not require government to be neutral about all doctrines? As Choper puts it, the public schools inay offer courses about "Dewey or Hegelor Keynes or Friedman, or Luther or Christ--" but for government to attempt to convince its citizens of the ultimate trutle of the teaching of any of these thinkers would be "ideological partisanship" that ought to be unconstitutional wholly apart froin the establishment clause. ${ }^{79}$ But could the schools - or other agencies of government-even try to convince people that it is wrong to cheat and steal, or to practice racial discrimination? What is needed, Choper concludes, is a colierent first ainendment doctrine capable of distinguishing " "narrow partisan ideologies' (whicl government may not subsidize or promote) froin . . . 'widely shared and basically noncontroversial public values'-such as the inherent dignity of the individual and the essential equality of all human beings-(which the state may aid or sponsor)."80 Abandoning the futile attempt to distinguish "religion" from ideology or philosoplyy leads us back to Professor Tribe's fear that the establishment clause might become an "awful engine of destruction" directed at government efforts to promote values that are themselves thought to liave a constitutional basis. ${ }^{81}$ As constitutional law expands to mclude a growing list of "fundamental values," should it be described as an established national civil religion or philosophy? Among the fundamental doctrines of our judicially defined constitutional philosophy are racial equality

77. See Choper, supra note 61, at 610-11.

78. "For example, the public schools might have voluntary programs of prayers to God seeking only worldly assistance, or state funds might be granted to a modern Protestant sect whose beliefs excluded salvation." Id. at 610 .

79. Id. at 612 .

80. Id.

81. See supra text accompanying note 72 . 
and integration (including intermarriage), ${ }^{82}$ a right to privacy (encompassing contraception and abortion), ${ }^{83}$ and an incompletely defined primciple of sexual equality (despite the failure of the Equal Rights Amendment). ${ }^{84}$ These doctrimes are not narrowly partisan, but they are not basically noncontroversial either.

Judicial decisions do not compel anyone to believe im anything, of course, but they certainly express an emphatic official endorsement of the moral or philosophical premises on which they rest. May the government expend public resources-im the schools or elsewhere-to encourage people to respect values which the courts have endorsed as fundamental to the American "concept of ordered liberty"? 85 Unless we can justify distinguishing rehgion from philosophy or whatever, then the U.S. Commission on Civil Rights, to name a single example, is engaged in establishing something imdistinguishable from a religion.

\section{Case-by-Case Adjudication}

Concluding that none of the attempts to formulate a constitutional definition of rehigion has been satisfactory, Professor Greenawalt writes in this Symposium that the attempt to settle upon any one definition is misconceived. ${ }^{86} \mathrm{He}$ argues that religion is such a coinplex subject that no single definition is likely to be satisfactory, and we must therefore proceed by the familiar common law inethod of case-by-case analogical reasoning. ${ }^{87}$ If we start with institutions or beliefs that are indisputably religious and coinpare doubtful cases of rehigion to the conceded ones, we can set each doubtful case on one side of the line or the other and gradually create a body of case law that can substitute for a true definition. ${ }^{88}$

Deciding each case by analogy is certainly a viable option, one which the courts have used often enough. But everything depends upon what we choose as the poimt of comparison from which to analogize. If we compare each doubtful case to the Episcopal Church, few philosophies will qualify as religions because they will lack the ceremomal superstructure. Yet if we coinpare the doubtful cases to the sort of

82. Bob Jones Univ. v. United States, 103 S. Ct. 2017 (1983).

83. Roe v. Wade, 410 U.S. 113 (1973).

84. Mississippi Univ. for Wonien v. Hogan, 458 U.S. 718 (1982). This case, which held the exclusion of quahified inales fron the School of Nursing of a state-supported university unconstitutional, was decided July 1, 1982, the day after the ratification period for the Equal Rights Amendinent expired.

85. See Palko v. Connecticut, 302 U.S. 319, 325 (1937), overruled on other grounds by Duncan v. Louisiana, 391 U.S. 145 (1968).

86. Greenawalt, supra note 63 , at 763 .

87. Id.

88. Id. at 769 n.60. 
philosophy of life that the Supreme Court found to be religious in Seeger ${ }^{89}$ everything that anyone believes in strongly will be a religion. Curiously, it is possible that some conventional churches would not be "religious" under the Seeger test, at least for their members who belong for cultural or social reasons and for whom the church is not a matter of "ultimate concern."

If we retain a creative tension between the poimts of comparison, each case will be an opportunity for creative reformulation. How we resolve the doubtful cases is not terribly important anyway, according to Greenawalt, because the subjective tests used to decide establishment and free exercise claims are sufficiently flexible that we can avoid "inapt" conclusions. ${ }^{90}$ The Rastafarians may be a religion, for example, but we do not have to let them smoke marijuana; ${ }^{91}$ neither do we need to allow a mendicant cult to keep its members' children out of school so that they can beg on the streets. ${ }^{92}$ Even if racial equality and feminism are in some sense religious doctrines, government can easily find a secular reason for promoting them.

My intention is not to denigrate the work of Tribe, Choper, or Greenawalt. Each did his best to work out a solution to an imtractable problem, and each advanced our understanding of just how intractable the problem is. Government must endorse some values, and does so every day. This is particularly true in public schools, which are as important as they are largely because we believe or liope that they can inotivate children to improve upon the values of their parents. Most people want our schools to teach children that it is wrong to cheat on tests, that it is wrong to treat people as intrimsically mferior because of their skin color or ethuric background, that it is wrong to limit arbitrarily the options available to people because of their sex, and that it is right to develop one's own capacity so that one can make a contribution to the community mstead of becoming a burden upon it. A public school that tried to be neutral about all such matters would be making the case for private education.

All-pervasive public neutrality caumot be the answer, nor can the answer be one that distinguishes between "clearly" and "arguably" religious philosophies to the advantage of one as opposed to the

89. See United States v. Seeger, 380 U.S. 163 (1965).

90. Greenawalt, supra note 63 , at 770 ; see also id. at 762.

91. See Whyte v. United States, 471 A.2d 1018 (D.C. 1984).

92. In Wisconsin v. Yoder, 406 U.S. 205, 222-26 (1972), the Court held that the Amish could withdraw their children from school after the eighth grade. The key element in the case was that the Amish continued to educate their children "vocationally" in a manner likely to prepare them to fnnction in ordinary society should they eventually leave the Amish community. The Court did not endorse the general notion that parents can remove their children from school by a simple invocation of some "religious" belief. 
other-unless some further justification can be advanced for the preference. Absent a better solution, we may well have no alternative but to decide cases by analogy as they arise, comforting ourselves with the thought that by defining something as "religion" we are not really committing ourselves to anything, because the subjective tests we employ from that poimt on give us more than enough maneuvering room to avoid any outcomes that we happen not to like.

A body of constitutional law certainly can be built upon that basis. The question is whether it ought to be. If first amendment law is based upon an arbitrary distimction between religion and every other forin of behef, why should the Supreme Court continue to employ the first amendment rehgion clauses to strike down legislation? The mability to define religion is not simply a problem that sometimes arises in particular cases; rather, it reflects a fundamental gap in first amendment theory. How can we say anything about religion if we do not know what it is?

IV

\section{IDEOLOGY AND COMPROMISE}

The preceding sections of this Article have attempted to establish the poimt that Supreme Court decisions in the religion area calmot be justified on the basis of the abstract legal concepts discussed in the opmions, because too much freedom exists im characterizing the issues and applying the subjective tests. Moreover, the doctrinal objectives are inherently contradictory, providing at once both a special legal position for religion and a principle that the law is not supposed to favor or disfavor rehigious belief. Finally, we have no principled definition of religion, and hence no way to justify treating religious beliefs differently from other behefs. Doctrinally, first amendment religion law is a mess.

Still, the fact that the constitutional doctrine is at times inuddled and internally mconsistent does not necessarily mean that it is intolerable. On the contrary, the very fact that the holdings do not fit any abstract pattern may indicate that the Court is steering a careful path between undue preference for religion (conventionally defined) and undue hostility to it. One major objective of the first amendment is to keep the public peace on religious issues, and one way of domg this is for every religious and antirehigious group to feel that the government is neither squarely on its side nor squarely on the other side. It is not good for anyone if a major ideological or social group becomes persuaded that the government consistently rejects its values or symbols. A body of decisions that is meant to keep the peace between strong contending factions may seem incoherent to those who wrongly sup- 
pose that the Court's purpose is to put into effect sone abstract doctrinal principles.

If we judge our constitutional law regarding religion on the basis of its acceptability to persons of widely differing religious opinions rather than its conceptual coherency, it looks a great deal better. For exainple, parents who desire a religious education for their children have a constitutional right to select this alternative. ${ }^{93}$ The state may not provide direct cash subsidies or tuition grants for such schools, but it may, if it chooses, provide free secular textbooks, bus transportation, and a certain measure of tax relief for educational expenses. ${ }^{94}$ Church and church-school property may be exeinpt from property taxes, ${ }^{95}$ and donations to religious institutions are exeinpt from incone tax, ${ }^{96}$ which nakes it relatively painless for well-to-do patrons to provide scholarship inoney for low-income students. Private schools tend to be less expensive to operate per student than public schools, in part because they do not have to support elaborate administrative structures and in part because they may not need to pay teachers as inuch. ${ }^{97}$ All these circumstances contribute to reducing the financial burden on parents who choose a religious education. Greater and more direct public subsidies would reduce the financial burden still inore, but possibly at the cost of inviting inore intrusive regulation of the schools' curriculum and administration. ${ }^{98}$ Persons favoring religious education have as much reason to fear basic change in the present legal compromise as to welcome it.

At the same time, establishment clause doctrine has given substantial support to the values of those who want a secular education and who do not want to be taxed to pay for religious alternatives. The religious intrusions that people seein to find inost offensive-teacher-led prayers and Bible readings in the classroom-have been banned, ${ }^{99}$ and

93. See id. at 213-14; supra note 23 and accompanying text.

94. See Mueller v. Allen, 103 S. Ct. 3062 (1983).

95. See Walz v. Tax Comm'n, 397 U.S. 664 (1970).

96. See Bob Jones Univ. v. United States, 103 S. Ct. 2017 (1983).

97. See M. Friedman \& R. FRJedMAN, Free to Choose 154-60 (1980).

98. It is frequently argued that religious schools must be protected from governinent subsidies in their own interest because their independence would be threatened by the regulation that tends to accompany the subsidies. After the decision in Bob Jones University, it appears that the existence of $\operatorname{tax}$ deductions can also be an invitation to government regulation. If tax deductions can be taken away from schools that practice racial discrimination, then why can they not be taken away fron schools that practice religious or sexual discrimination as well? Even in the absence of "tax subsidies," states can and do regulate private schools, including religious schools. We shonld, therefore, be careful not to overestimate the degree to which the independence of religious schools is protected by any constitutional doctrines. Nevertheless, it is likely that regular appropriations bills for direct subsidies would inspire legislators to think about regulating rcligious schools more frequently than they do now.

99. School Dist. v. Schempp, 374 U.S. 203 (1963); Engel v. Vitale, 370 U.S. 421 (1962). 
the majority of voters who favor allowing some prayer have been unable to overturn the ban. ${ }^{100}$ Some public assistance does go to private schools, many of which are religious, but the fact that the aid is limited and indirect seems to reduce the degree to which it is offensive to persons who would prefer no aid at all. Apparently, it is not so much the dollar amount of the aid that generates resentment as whether the aid is provided in a way that seems to associate the state with a particular religious practice. ${ }^{101}$

Public endorsement of controversial religious symbols outside the classroom has also been strictly limited. The exceptions are sufficiently limited that they prove the rule. The significant thing about the holding of Lynch v. Donnelly ${ }^{102}$ from this viewpoint is not that the Court allowed the city to contimue including a nativity scene in its Christmas display, but that the vote was so close and the decision justified on such narrow grounds. ${ }^{103}$ Militant secularists do not wim all the battles, but they too have reason to view the overall situation with at least partial satisfaction.

The free exercise cases are also easier to understand as exercises im political compromise rather than as a working out of abstract constitutional concepts. Regulations of general applicability that are quite reasonable as applied to most people may require some unusual mdividuals or groups to violate their most deeply held beliefs. Where an exemption can be given without substantially impairing the state or federal government's imterests, the Court can invoke the free exercise

100. There is evidence that approximately $80 \%$ of the public favors allowing some form of school prayer. See Smith, Book Review, 72 Calif. L. Rev. 908, 913-14 (1984) (reviewing H. McClosky \& A. Brill, Dimensions of Tolerance: What Americans Believe About Civil. LIBERTIES (1983)). In the 1984 Term, the Supreme Court will consider the constitutionality of legislation providing for silent prayer in public schools.

101.

Because of the symbolic role of elementary and secondary education-because of the special place that such education has in our society-the Court las been particularly careful to avoid government programs that would provide economic aid directly and conspicuously to elementary and secondary parochial schools. . . . [Every] dollar spent on police or fire protection for churcl-afiliated schools and colleges is a dollar released from their budgets, and hence a dollar they are free to spend on religious activity. But the provision of such secular services is not offensive because no one perceives police or fire protection as part of the educational enterprise. Such aid goes to institutions not as schools but as parts of the general public. Similarly, aid for secular programs in all colleges, including those with church affiliation, is generally perceived as assistance to non-religious activities. But the moment aid is sent to a parochial school as such, it is widely seen as aid to religion. The number of dollars released for religious purposes may be identical; the symbolisin, and hence the constitutional result, is not.

L. TRIBE, supra note 3, at 843-44.

102. 104 S. Ct. 1355 (1984).

103. "[G]iven the Court's focus upon the otherwise secular setting of the Pawtucket creche, it remains uncertain whether absent such secular symbols as Santa Claus' house, a talking wishing well, and cut-out clowns and bears, a similar nativity scene would pass inuster under the Court's standard." Id. at 1370 n.l (Brennan, J., dissenting). 
clause to require the exemption. Avoiding unnecessary confrontations over issues of basic principle is an important part of the art of democratic government.

Cases like Sherbert v. Verner ${ }^{104}$ and Wisconsin v. Yoder ${ }^{105}$ tend to trouble the legal mind because they mvolve a mild form of discrimination on rehigious grounds, and because they involve subjective judgments about how smcere a particular group is, how important various beliefs or practices are to it, and how adversely the public interest will be affected by a special exeinption. In Yoder, the Court's opinion left no doubt that the decision turned largely on the respect the Justices had for the Old Order Amisl and their long historical struggle to preserve their distinctive way of life. The opimion warned that other groups with different characteristics should not necessarily expect smilar treatment. ${ }^{106}$ It is not easy to achieve this kind of outcome by a neutral application of legal concepts; rather, what the Court did looks more like an act of prosecutorial discretion or executive clemency. Legal scholars struggle to justify what the Court does on neutral principles; but perhaps it would be more honest simply to acknowledge that the Court occasionally gives a deserving party a break.

Behind the compromising and interest balancing that characterizes the constitutional law of religion lies a major ideological issue. Are the prevailing rehigious behefs beneficial on the whole to a pluralistic deinocratic society, or are they something that we tolerate and endure despite their social costs? Would it be desirable if fewer people held theistic behiefs, or at least held them less passionately? In some quarters, religious belief (at least in the traditional sense) is associated with persecution, obscurantism, and social strife, and the religious groups most prone to these evils are thought to be the ones most likely to seek government support. ${ }^{107}$ On the other hand, there are many others who consider Judeo-Christian religious belief to be an important positive force in building the values of a democratic citizenry, and who associate loss of religious faith with a permissiveness that tends to undermine private and civic virtue. The social value of religion $\mathrm{m}$ general is an extremely complex topic, of course, but people do tend to have attitudes about it. Consciously or unconsciously, those attitudes affect how we apply subjective tests, or how we choose to characterize constitutional questions. ${ }^{108}$ The state ought to inamtain a "wall of separa-

104. 374 U.S. 398 (1963).

105. 406 U.S. 205 (1972).

106. Id. at 235-36.

107. Smith, supra note 100 , at 915-16.

108. For an illnminating discussion of the personal views of various Suprcme Court Justices about religion, and the extent to which those views influenced their attitudes towards the religion clauses, see Smith, supra note 2, at 105-23. Smith draws a useful distinction between corporate 
tion" between itself and creeds which are prone to encourage intolerance and ignorance. "Benevolent neutrality" is a more appropriate paradigm for dealing with creeds that promote virtues that help to maintaim the health of the republic, or are at least harmless.

Of course the category "religion" incorporates creeds with a variety of vices and virtues, and we may well feel differently about the category as a whole, depending upon which exainples we have in mind. Sorne legal issues characteristically involve specific kinds of religion. For example, the Supreme Court first invoked the "wall of separation" inetaphor against aid to religious schools in a context where the only schools receiving the aid were Roman Catholic, ${ }^{109}$ and at a time when many Americans regarded the Catholic church as a semitotahtarian menace to their liberties. Paul Blanshard's influential book American Freedom and Catholic Power, ${ }^{110}$ characterized the Catholic church as an antidemocractic "state within a state," "11 which aimed to impose its own law upon Catholics and non-Catholics alike. ${ }^{112}$ Blanshard saw the Catholic schools as substantially inferior to the public schools academically, with teaching assigned to undereducated and overdisciplined nuns who were primarily concerned with indoctrimating the children to be obedient to the Cliurch and its priests. ${ }^{113}$ Because the Cliurch required Catliolic parents to send their children to parochial schools or suffer denial of absolution for their sims, attendance at those schools was not truly a matter of personal or family choice. ${ }^{114}$ All other American religious groups were satisfied with the public schools and their education, according to Blanshard; ${ }^{115}$ only the Catholic hierarchy de-

religion and individual religion. Many Justices sympathetic to individual religion were or are intensely suspicious of "corporate religion," particularly the Roman Catholic Clrurcli. Not surprisingly, those Justices who tend to regard corporate religion as greedy, totalitarian and intellectually backward have tended to be activist in interpreting the first amendment to forbid government assistance to religion. Id. at 105-13.

109. See Everson v. Board of Educ., 330 U.S. 1 (1947).

110. P. Blanshard, American Freedom and Catholic Power (1949). To illustrate the work's influence, more than 100,000 copies of the book were sold in the first nine months following publication. $I d$. at copyright page.

111. See id. at 4.

112. Id. at $3-4$.

113. "[Teaching nuns] are never allowed to forget that they are primarily religious missionaries whose chief mission is the inculcation of the Cathotic faith." Id. at 69.

114. Id. at 65 .

115.

The attitude of most non-Catholic Americans toward public support for Catholic schools might be summed up in this fashion: The Catholic people liave been offered the same free, democratic schools that lave been offered to everybody else. If they do not wisls to join the rest of the American communty, that is their affair. Methodists, Baptists, Jews, and nearly everybody else except Catholics belong to the great fraternity of American public education. The Catholic people have not been blackballed; they have been elected to full membership, but their priests have persuaded thein to stay away from the meeting. They slrould not pretend that they are being discriminated against. Method- 
manded something different-and "un-American."116

The poimt here is not to examine the extent to which Blanshard's polemic was a caricature of the Catholic church in 1949. However fair or unfair, American Freedom and Catholic Power stated a view of the Catholic hierarchy that was widespread among Americans at the time of the cases that set establishment clause doctrine on its present course-a time when the possible election of a Catholic president aroused the deepest fears. To the extent that they accepted Blanshard's account as substantially true, judges would understandably be attracted to a constitutional theory that disfavored public subsidies for nonpublic schools. Granted Blanshard's premises, or even somewhat less extreme ones, it was simply a matter of self-preservation for non-Catholics to interpret the Constitution im a mamier likely to hamper, rather than encourage, the anticonstitutional plans of the Catholic hierarchy.

Attitudes toward both the Catholic church and its schools have changed a great deal since the 1940 's, reflecting such developments as the reforms of the Second Vatican Council and the election of a Catholic President. Today, the Catholic schools are staffed primarily with lay teachers rather than nuns, and a high percentage of the pupils in some cities are non-Catholics whose parents were presumably attracted by the quality of the education rather than by any program of religious indoctrimation. ${ }^{117}$ Some studies have compared the performance of the Catholic schools very favorably to that of the public schools in educatmg low-mcome minority pupils in inner-city areas. ${ }^{118}$ If these studies are reliable, the Catholic schools are performing a service of enornous value to the society as a whole.

Attitudes toward the public schools have also changed. Most nonCatholic Americans may have been satisfied with the public schools in 1949 , but clearly they are satisfied no longer. Widely publicized problems of violence, drug use, and low academic achievement have motivated many parents to search for alternatives, whether secular or religious. In many places, enrollment at Protestant Christian schools has imcreased enormously, and there is serious discussion of "voucher" plans which would permit students to attend private schools at public

ists, Baptists and Jews cannot collect public funds for their schools. Neither can

Catholics. We must treat everybody alike.

Id. at 88 .

116. Blanshard urged "continuous and scientific inspection of all parochial schools to see that the standard requirements of the state are maintamed, that classes are taught in the English language, and that textbooks do not distort history, science and sociology in an un-American inanner for the benefit of the hierarchy." Id. at 304-05. He described Catholic schooling as based on "a whole philosophy of education that is alien to the American outlook." Id. at 65.

117. For statistics and references on this point, see Laycock, supra note 47, at 1387 n.119.

118. See id. at 1387 n.118. 
expense. ${ }^{119}$ These developments are controversial. Many persons are no more enthusiastic about Protestant Fundamentalism than Paul Blanshard was about the Catholic church, and to some degree the enthusiasm for private education may be related to court-ordered racial integration. ${ }^{120}$ The point here is not to decide whether public assistance for private education is ultimately a good or a bad idea, but merely to note that the context in which the constitutional issues arise has changed enormously simce the 1940's. To the extent that programs of aid to private education are seen as meeting a widespread desire for alternatives to publicly administered education, permitting religious schools to participate may seem more like avoiding discrimination against religion, rather than creatimg a religious establishment. ${ }^{121}$

\section{CONCLUSION}

It is no contradiction to say that the constitutional law of religion reflects both ideological bias, and an attempt at "neutral" compromise among conflictimg ideological viewpoints about religion. Fortunately, one widely shared ideological premise im American society is that allout religious conflict must be avoided, which implies that we should make strenuous efforts to avoid idcntifying government squarely with any religious position, imcluding antireligion. Government must seem to be evenhanded about religious disputes. What it does may coincide with the wishes of some groups and thwart the plans of others, but this coincidence must seein to be the outcome of neutral primciples or fairminded interest balancing, rather than conscious partisanship on the part of judges. The emphasis upon neutrality is not necessarily deceptive. Most judges want to be fairminded and to arrive at a solution that seems reasonable from as many poimts of view as possible. To say that they are influenced by ideology is not to say that they are ideologues.

There is never only one possible compromise, and neutrality can be more or less benevolent, depending upon what we think we are bemg neutral about. We may have to be "neutral" with respect to anach-

119. See J. Coons \& S. Sugarman, Education by Choice (1978); M. Fruedman \& R. FRIEDMAN, supra note 97, at 150-75.

120. For illuminating discussions of the racial aspects of the growth in Christian schools, see Rabkin, Behind the Tax-Exempt Schools Debate, PuB. INTEREST, Summer 1982, at 21; Skerry, Christian Schools versus the I.R.S., PUB. INTEREST, Fall 1980, at 18.

121. Groups whose real interest is to protect the public schools from coinpetition can be expected to continue to invoke the establishment clause as a useful weapon for protecting their economic interests. In California Teachers Ass'n v. Riles, 29 Cal. 3d 794, 632 P.2d 953, 176 Cal. Rptr. 300 (1981), the California Supreme Court ruled that the state constitution's ban on aid to sectarian schools prohibited a state program providing free textbooks for private schools. $C f$. Wolman v. Walter, 433 U.S. 229 (1977). Although inost of the schools that received the textbooks had some religious affiliation, I am confident that the teachers' union that brought the lawsuit was primarily interested in protecting the jobs of its inembers from private sector competition. 
ronistic superstitions that serve the interests of fanatics and unscrupulous power seekers, but we can seek the definition of neutrality that least facilitates their advancement. We may have to avoid "establishing" groups that promote moral truths and serve the cause of liberty rightly understood, but we do not have to erect unnecessary obstacles for their beneficial activities. Inherited legal doctrine and social convention restrict the choices that a lawyer is likely to consider legitimate; ideological preference governs the exercise of choice among alternatives perceived as legitimate. ${ }^{122}$

We ought not to be slocked at the frank acknowledgment that our attitudes about religious truth and the social value of prevailing religious practices imfluence low we choose to interpret the Constitution's mysterious phrases. Ideology organizes reality for use, and we cannot decide what to do about law or anything else witlout relying on soine picture of reality, incomplete and distorted thougli it nay inevitably be. One vital component of our ideology is the extent to which it perinits us to consider that radically differing groups may each be glimpsing a part of reality through their own distorting lenses. Ideological bias is not itself inconsistent with fair adjudication; on the contrary, it provides an indispensable starting point for the inquiry into what fairness means in a particular context. What we need to fear is not ideology but ideological blindness, mcluding the blindness that takes the form of imagining that one's own views are derived logically froin premises acknowledged by all reasonable persons.

122. When Professor Mansfield refers to a "constitutional philosophy," he may mean the same thing that I call "ideologicaI preference." Mansfield, The Religion Clauses of the First Amendment and the Philosophy of the Constitution, 72 CALIF. L. REv. 847 passim (1984). I am uncertain about this because Mansfield does not explaim how the constitutional philosophy is generated or whether it is something distinct from the philosophies of particular Justices who participate in writing opinions. Using his language, I would say that each Supreme Court Justice has a philosophical perspective which he or she employs when deciding cases. A constitutional philosophy arises because a number of Justices happen to agree on certain principles over a period of time, and inuplicitly rely upon those principles in writing opinions. The constitutional philosophy is likely to change as new members are appointed to the Court, or as continuing Justices change their ways of thinking. Perhaps it would be more aceurate to speak of a "Supreme Court philosophy," because the constitutional philosophy is not derived in any direct way from the document whose authority it invokes. 